\title{
Iraq in the American Presidential Debate Discourse: A Critical Discourse Analysis
}

\author{
Huda H. Khali1 ${ }^{1} \&$ Nawal F. Abbas ${ }^{1}$ \\ ${ }^{1}$ Department of English, College of Education for Women, University of Baghdad, Baghdad, Iraq \\ Correspondence: Huda H. Khalil, Department of English, College of Education for Women, University of \\ Baghdad, Jadiriya, Baghdad, Iraq. E-mail: hudahadi7@yahoo.com
}

Received: November 8, 2017 Accepted: November 29, $2017 \quad$ Online Published: December 23, 2017

doi:10.5539/ijel.v8n2p260 URL: http://doi.org/10.5539/ijel.v8n2p260

\begin{abstract}
The present paper aims at identifying both the American Republican and Democratic presidential nominees' (Hillary Clinton's and Donald Trump's) ideologies towards Iraq in the only three American presidential debates held before the presidential elections of 2016. The presidential nominees participated in the three debates have been the same (Clinton and Trump). These debates have synchronized with one of the toughest periods in which Iraq was fighting ISIS. To arrive at these ideologies, the three presidential debates discourse has been critically analyzed depending on Van Dijk's socio- cognitive approach. The linguistic tools selected as means to manifest the ideologies are global topics, local semantics and speech acts. The analysis has shown that the three American presidential debates represent a rich ideology discourse and that both Clinton and Trump share certain ideologies towards Iraq but differ in the majority of these ideologies. Both presidential nominees have taken advantage of the issue of Iraq in the debates to achieve certain electoral benefits.
\end{abstract}

Keywords: critical discourse analysis, global topics, Iraq, local semantic, presidential debate discourse, speech acts

\section{Introduction}

Critical discourse analysis might best be seen as a "problem-oriented interdisciplinary research movement, subsuming a variety of approaches which are united by "a shared interest in the semiotic dimension of power, injustice, abuse and political economic or cultural change in society" (Fairclough, Mulderrig, \& Wodak, 2011, p. 357). Scholars of critical discourse analysis are "sociopolitically committed to social equality and justice" and they are interested in "the discursive (re)production of power abuse and the resistance against such domination" (Van Dijk, 2009, p. 63). In this sense, critical discourse analysis deals with problems rather than disciplines and, thus, "requires a multidisciplinary approach" (Van Dijk, 2009, p. 63).

Critical discourse analysis is not restricted to a particular topic, a type of discourse or a type of medium and it uses "a variety of types of methodology" (Waugh, Catalano, Al Masaeed, Hong Do, \& Renigar, 2016, p. 72). Conducting a critical discourse analysis, the analyst typically goes beyond the common theories of the structure of discourse describing the way discourse plays a role "in the (re)production of power abuse, or against such domination, in society" (Van Dijk, 2009, p. 72). Critical discourse analysis aims at identifying "structures, strategies or other properties of text, talk, [and] verbal interaction" that contribute in the reproduction of "power relations ..., enactment, representation, legitimation, denial, mitigation or concealment of dominance ...." (Van Dijk, 1993, p. 250). The analysts' scholarly practices (goals, theories, methods and data) are considered "as academic contributions to such resistance" (Van Dijk, 2009, p. 63).

\section{The Socio- Cognitive Approach}

Social interaction and discourse influence one another by the "cognitive interface of mental models, knowledge, attitudes and ideologies" (Van Dijk, 2009, p. 64). Because critical discourse analysis is more "interested in power, domination and social inequality" and "tends to focus on groups, organizations and institutions", it has to put into consideration "the various forms of social cognition that are shared by these social collectivities: knowledge, attitudes, ideologies, norms and values" (Van Dijk, 2001, p. 113).

In the application of the socio- cognitive approach in practical works, Van Dijk has mainly tackled "stereotypes, the reproduction of ethnic prejudice, and power abuse by elites and resistance by dominated groups" 
emphasizing "the control of discourse dimensions as a means to gain access to power" (Tenorio, 2011, p. 190).

According to Fairclough (2001, p. 16), the texts themselves do not represent the ultimate goal of a critical discourse analyst; rather, special attention needs to be directed towards how the cognitive processes by these texts are produced and interpreted can change with social and historical changes. The cognitive component of the socio- cognitive approach deals with mind or memory and "the cognitive processes and representations involved in the production and comprehension of discourse" (Van Dijk, 2009, p. 66). In the brain, the memory is divided into:

1). Working memory (WM) which is also called Short Term Memory (STM)

2). Long Term Memory (LTM)

3). Episodic Memory (EM)

4). Semantic Memory (SM)

The Long Term Memory (LTM) spotlights "remembrances of autobiographical experiences and knowledge stored in Episodic Memory (EM)" and "socially shared knowledge, attitudes and ideologies in the Semantic Memory (SM)" (Van Dijk, 2009, p. 66). Van Dijk (2002, p. 208) uses the term "Social Memory" to refer to the semantic memory contrasting it with "the more personal information stored in the Episodic Memory".

The personal experiences (visual, auditory, sensorimotor, evaluative, or emotional ones) are processed in the Working Memory (WM) in the form of "mental models, stored in the Episodic Memory" (Van Dijk, 2009, p. 66). Mental models serve as "interface between socially shared political cognitions ... and personal beliefs ..." and they represent the "cognitive basis of political discourse and political action" (Van Dijk, 2002, pp. 207-209). These models are "subjective representations of events or situations, in which a person participates at a certain moment of time, at a certain place, with other participants...engaged with a specific action and with specific goals" (Van Dijk, 2012, p. 588 cited in Al-Momani, 2017, p. 91).

Discourse is produced and understood on the basis of the above cognitive structure in that the components of discourse (words, phrases, clauses, sentences, paragraphs or turns) are "processed in WM and represented and controlled by the mental models, knowledge (and sometimes ideologies) in LTM." (Van Dijk, 2009, p. 67). In other words, "contexts should be defined in terms of participants' mental models of communicative events" (Van Dijk, 2002, p. 225).

\subsection{Knowledge}

Knowledge refers to the beliefs that concur the epistemic community. Assumingly, this knowledge is "locally organized by hierarchical categories of concepts and schemas of different types, such as scripts of everyday episodes, schemas of objects, persons or groups of people, and many more" (Van Dijk, 2009, p. 68). The general social knowledge is part of the personal mental model which represents personal "experiences, perceptions and interpretations of events and situations" (Van Dijk, 2009, p. 68).

Van Dijk (2001, p. 114) distinguishes three kinds of knowledge: personal knowledge, group knowledge and cultural knowledge:

Personal knowledge is represented in mental models about specific, personal events.... Group knowledge is shared by specific social groups, such as professionals, social movements or business companies.... Cultural knowledge is shared by all competent members of a society or culture, and forms the basis or common ground of all social practices and discourses.

\subsection{Attitudes and Ideologies}

Ideology is a cognitive and social conception forming a framework "for organizing the social cognitions shared by members of social groups, organizations or Institutions" (Van Dijk, 1995, pp. 17-18). It works as an "interface" between the "cognitive representations" of discourse and action and "the societal position and interests of social groups" (Van Dijk, 1995, p. 18).

Attitudes and ideologies are forms of social beliefs that are only shared by specific groups. For example, in Europe, most people know what immigration is, but some groups may have different attitudes about it (being good or bad) depending on their ideologies (Van Dijk, 2009, p. 69). Ideologies can be variably and indirectly expressed in texts and talk and discourses "function to persuasively help construct new and confirm already present ideologies" Van Dijk (1995, p. 22).

\subsection{Power and Domination}

Power is one feature that characterizes the "relations between social groups, institutions or organizations" (Van 
Dijk, 1993, p. 84). Critical discourse analysis is more interested with the social power which represents "the control exercised by one group or organization ... over the actions and/or the minds of ... another group" leading to limitation and influence upon the others' action, "knowledge, attitudes or ideologies" (Van Dijk, 1993, p. 84).

The exercise of power could be legitimate such as "in democratic societies or between parents and children in families" (Van Dijk, 2009, p. 71). However, critical discourse analysis is concerned with "power abuse or domination" which can "be defined in terms of legitimacy and the violation of social norms and human rights" (Van Dijk, 2009, p. 71). In this case, control is in the favor of the more powerful group and against the desire of the less powerful group. Thus, dominance is "a form of social power abuse, that is ... a legally or morally illegitimate exercise of control over others in one's own interests, often resulting in social inequality" (Van Dijk, 1993, p. 84). Rather than being "absolute", dominance is often "gradual" and usually confronted by "more or less resistance or counter-power by dominated groups" (Van Dijk, 1993, p. 85).

\section{The American Presidential Debates (2016) and Iraq}

Since 2003, the United States of America has played an effective role in shaping the continuously changing situation in Iraq. In spite of the almost unified American presidents' policy towards Iraq, there have been certain discrepancies decided by the current circumstances and conditions that Iraq has undergone. After April, 2014, "the security situation in Iraq has witnessed serious escalation ... when important Iraqi cities have been conquered by the ISIS" (Khalil, 2017, p. 330). The period between April, 2014 and October, 2016 (when the Iraqi military forces started liberating cities conquered by the ISIS) was a tough one for the Iraqis in general. At the beginning, the Iraqi people had expectations that America would take more serious steps to stop the ISIS militants flowing from Syria and other parts of the world. In the second half of 2016, the Iraqi government (supported by the Islamic Jihad Fatwa against ISIS launched by the chief of the Shiite community in Iraq) started taking decisive steps to liberate the Iraqi vast areas that the ISIS took hold of. It was not an easy fast settled battle; the Iraqi militants have faced fierce well- equipped forces. Thus, the period after October, 2016 has been a critical one for the future of Iraq and it has synchronized with the American presidential elections in November, 2016.

Before these American presidential elections, there have been three American presidential debates (organized by The Commission on Presidential Debates (CPD)) between the Republican nominee Donald Trump and the Democratic nominee Hillary Clinton. These three debates represent the corpus analyzed in the present paper. The issue focused on in the paper is Iraq, in one of its most critical periods of history, as directed by a future president of America as one of the most influential nations on the situation in Iraq. The paper mainly aims at figuring out the underlying ideologies of each political party nominee (Republican and Democratic) with respect to Iraq.

Concerning the relation between the linguistic tool and ideologies, van Dijk (1998, p. 233) asserts that "ideologies may in principle map onto all levels and dimensions of discourse: graphics, intonation, syntax, local meanings and coherence, topics, style, rhetoric, speech acts and interactional features". A critical discourse analysis researcher may advocate and develop any method to critical linguistics, but "not all of them have to be helpful in the same discourse and it is not necessary to use all the devices or to use them in exactly the same way in specific research projects" (Jin \& Shang, 2015, p. 57).

The linguistic tools selected in the present paper as means to manifest the ideologies are global topics, local semantics and speech acts for their characteristics as being valid means for demystifying the upcoming American ideologies towards Iraq. For the importance of global topic and local semantics in ideology presentation, Van Dijk (1998, p. 207) states that "semantics is a rich field of ideological "work" in discourse, and virtually all meaning structures are able to "signify" social positions, group perspective and interests in the description of events, people and actions". Speech acts have been chosen in the present paper because, as Van Dijk (1998, p. 209) believes, they directly show "the ideological control of social practices". Moreover, "whenever relations between participants as well as other dimensions of the context (time, location, etc.) are ideologically based, this may show up in the kind of speech acts being accomplished by the participants" (Van Dijk, 1998, p. 209).

\section{Global Topics}

It is also referred to as global semantics or semantic macrostructures. It is important for communication and interaction and they depend on local semantics (the local microstructure of meaning). It is what a discourse is globally about explaining the global coherence in a text or talk. These semantic macrostructures "define what speakers, organizations and groups orient towards and that has most impact on further discourse and action" (Van Dijk, 2001, p. 102). 
Although these topics are inferred from discourse by language users, "they are often expressed in discourse, for instance in titles, headlines, summaries, abstracts, thematic sentences or conclusions" which a language user can use to deduce global topics (Van Dijk, 2001, p. 102). It is preferable to start with global topic analysis because "[i]t provides a first, overall, idea of what a discourse or corpus of texts is all about, and controls many other aspects of discourse and its analysis" (Van Dijk, 2001, p. 102).

\section{Local Semantics}

It is also referred to as local meanings represented by "the meaning of words ..., the structures of propositions, and coherence and other relations between propositions" (Van Dijk, 2001, p. 103). Such an analysis comes next to global topics. Local meanings "are the result of the selection made by speakers or writers in their mental models of events or their more general, socially shared beliefs" (Van Dijk, 2001, p. 103). They "influence the mental models, and hence the opinions and attitudes of recipients" (Van Dijk, 2001, p. 103).

For the relation between local semantics and ideology (which is relevant for the following paper), Van Dijk (2002, p. 231) states:

[A] cognitively based political analysis of local meanings will try to relate the selection of propositions expressed in text and talk to underlying event and context models as well as socially shared (group) representations such as knowledge, attitudes and ideologies. Thus... local meaning ... will typically be a function of the ideologically based event models.

Critical discourse analysis is interested in "implicit or indirect meanings, such as implications, presuppositions, allusions, vagueness..." entailment and so on (Van Dijk, 1998, p. 207 \& Van Dijk, 2001, p. 104). Local and global semantics define a great deal of the context model in a political discourse and, according to cognitive psychology, "such meanings are based on underlying mental models" (Van Dijk, 2016, p. 7).

\section{Speech Acts}

Uttering words in a text and talk is actually "the accomplishment of a large number of social actions" and "participating in social interaction" (Van Dijk, 1998, p. 208). Speech acts "are ... defined in terms of social conditions of participants, namely, their mutual beliefs, wants, intentions, evaluations and goals that have social implications" (Van Dijk, 1998, p. 208).

Van Dijk (1995, p. 30) states that "the social control of speech acts should operate through context models that represent the communicative situation and its participants, goals, and other relevant appropriateness conditions".

\section{Analysis, Results and Discussion}

The scripts of the three debates held before the American Presidential elections in 2016 have been downloaded from the website of The Washington Post (https://www.washingtonpost.com) as one of the top daily newspapers in America.

\subsection{The First Debate}

The participants are the Democratic nominee, Hillary Clinton, and the Republican nominee, Donald J. Trump. The debate was held in September 26, 2016. According to the statement of the moderator at the beginning of the debate, the debate has been devoted for three main topics; "[a]chieving prosperity; America's direction; and securing America" (https://www.washingtonpost.com/news/the-fix/wp/2016/09/26/the-first-trump-clinton-presidential-debate-transc ript-annotated). It is important to make clear the point that the present paper focuses on the ideologies of the Democratic Party (represented by Clinton) and the Republican Party (represented by Trump) separately towards Iraq as a country whose security is threatened by terrorist forces (Al- Qaida before and then the ISIS) and not towards the ISIS themselves.

In the present paper, however, global topics have been investigated only in relation to the parts of the debate in which Iraq is addressed or mentioned. In such a case, the global topic depends mostly on the issued raised by the moderate's question.

The moderator has asked each nominee the same set of questions and two minutes have been allotted for each response. In the first part of the debate, devoted to achieving prosperity (through tax management and job supply in America), Iraq has not been referred to in one way or another since the issue is pretty much internal and the same thing applies to the second part of the debate, devoted to America's direction (discussing race division and crime in America). In the third part, devoted to securing America, Iraq has appeared in the moderator's question and the nominees' answers. The global topics identified here have nothing to do with the topic of the part of the debate in which Iraq is mentioned (securing America) since the focal point here is the nominees' opinion. 
Ignoring the moderator's question since it does not represent the opinion of any of the nominees, the global topics related to Iraq for the nominees of the two parties are as follows:

Table 1. Clinton's global topics in the 1st debate

\begin{tabular}{ll}
\hline & Clinton \\
\hline 1 & Field war against ISIS to expel them from Iraq and squeeze them in Syria \\
2 & Iraq is unsecure place for the American troops to stay in \\
3 & The American war in Iraq in 2003 was not a mistake \\
\hline
\end{tabular}

Table 2. Trump's global topics in the 1st debate

\begin{tabular}{ll}
\hline Trump & \\
\hline 1 & America is the reason behind the bad situation in Iraq \\
2 & Iraq needs America to stay secure \\
3 & The American war in Iraq in 2003 was a mistake \\
\hline
\end{tabular}

The speech about fighting ISIS in Iraq and other parts of the world has come when the moderator asked the nominees a question about fighting cyber-attacks performed by ISIS and other groups in the world against the American institutions. Clinton has assured the importance of fighting ISIS in Iraq, but Trump has accused President Obama and Secretary Clinton to create "a vacuum the way they got out of Iraq" (https://www.washingtonpost.com/news/the-fix/wp/2016/09/26/the-first-trump-clinton-presidential-debate-transc ript-annotated). These conflicting ideas have led to the first global topics of the two nominees.

Then Trump has assured that ISIS cannot be expelled out of Iraq without the American military intervention accusing Obama's government (and Secretary Clinton as part of that government) of creating a vacuum in Iraq and giving a chance to ISIS to grow bigger. In response to that accusation, comes the second global topic when Clinton has declared that Iraq is not a safe place because the Iraqi government then could not provide protection for the American troops.

Then, the two nominees have started searching for justifications for their view points. The global topic managing their justifications is the 2003 war in Iraq upon which the two nominees totally disagree, as shown in the tables above.

Depending on the three global topics deduced from Clinton's speech, the ideologies of apprehension and insecurity can be figured out because, according to Clinton, America needs to fight in Iraq to reduce the danger of ISIS which represents a source of threat to America, Iraq is an insecure place for the American troops to stay in military bases and America had to start a war in Iraq in 2003 to secure the world.

Depending on the three global topics deduced from Trump's speech, the ideology of victimization is identified since, according to Trump, America has done unjust to Iraq when it (America) launched the war in 2003 to defeat Saddam's regime and, then, leaving Iraq without protection for terrorist to settle in and, eventually, leading to the security deterioration in Iraq.

At the level of local semantics, the analysis starts with Clinton. In the extract below, she has expressed Obama's government role in fighting ISIS in Iraq:

We're making progress. Our military is assisting in Iraq. And we're hoping that within the year we'll be able to push ISIS out of Iraq and then, you know, really squeeze them in Syria.

But we have to be cognizant of the fact that they've had foreign fighters coming to volunteer for them, foreign money, foreign weapons, so we have to make this the top priority.

And I would also do everything possible to take out their leadership. I was involved in a number of efforts to take out Al Qaida leadership when I was secretary of state, including, of course, taking out bin Laden. And I think we need to go after Baghdadi, as well, make that one of our organizing principles. Because we've got to defeat ISIS, and we've got to do everything we can to disrupt their propaganda efforts online (https://www.washingtonpost.com/news/the-fix/wp/2016/09/26/the-first-trump-clinton-presidentia 1-debate-transcript-annotated).

There is obvious optimistic sense in her speech about America's role in fighting ISIS in Iraq which is clear in the lexicalization (as in making progress and assisting). Moreover, the hyperbolic use of the words push and squeeze 
suggests dynamic powerful American situations over the other helpless side. The use of the model auxiliary will with the word able (referring to America) in we'll be able to push ISIS out of Iraq and then, you know, really squeeze them in Syria is an implicit indication for a better future for ISIS free future Iraq, but only through the ability of America. Another important lexicalization application is the use of the word foreign to identify the source of support (fighters, money and weapons) produced for ISIS militants in Iraq. With this part of the debate, she has killed two birds with one stone; she has implicitly blamed other countries to support ISIS in Iraq and, at the same time, acquitted America from taking part in worsening the situation in Iraq by accusing foreign supporters.

In the last part of the extract, Clinton has recalled the killing of Osama Bin Laden (head of Al-Qaeda) in May 2, 2011 by the United States Navy SEALs of the U.S. Naval Special Warfare Development Group during the presidency period of Obama. Clinton, at that time, was the United States Secretary of State. This way, she has foreshadowed the killing of Baghdadi (head of ISIS in Iraq and Syria). There has been an apparent tone of determinism in her speech identified by lexicalization in the clause we've got to defeat ISIS the way she took part in defeating Al-Qaeda and their leader before.

According to the speech above, together with the analysis, the ideology of domination is identified; America is dominating the safety of Iraq from ISIS.

In response to the moderator's question about how to secure America from homegrown attacks, Trump says:

Well, first I have to say one thing, very important. Secretary Clinton is talking about taking out ISIS. "We will take out ISIS." Well, President Obama and Secretary Clinton created a vacuum the way they got out of Iraq, because they got out - what, they shouldn't have been in, but once they got in, the way they got out was a disaster. And ISIS was formed.

So she talks about taking them out. She's been doing it a long time. She's been trying to take them out for a long time. But they wouldn't have even been formed if they left some troops behind, like 10,000 or maybe something more than that. And then you wouldn't have had them.

Or, as I've been saying for a long time, and I think you'll agree, because I said it to you once, had we taken the oil - and we should have taken the oil-ISIS would not have been able to form either, because the oil was their primary source of income. And now they have the oil all over the place, including the oil —a lot of the oil in Libya, which was another one of her disasters (https://www.washingtonpost.com/news/the-fix/wp/2016/09/26/the-first-trump-clinton-presidential-debate-t ranscript-annotated).

In the first part of the extract above, the propositions expressed in the sentences are all about accusing President Obama and Secretary Clinton of forming ISIS in Iraq indirectly through overthrowing Saddam's regime and creating proper conditions for ISIS to form. There is presupposition here in that the creation of ISIS presupposes a vacuum and creating vacuum entails that the atmosphere has been quite suitable for terrorist forces (like ISIS) to be active and take over authority. Lexicalization in this part of Trump's speech (created a vacuum, they shouldn't have been in and disaster) has emphasized Trump's view point about Obama and Secretary Clinton misbehavior.

In the second part of the extract, the use of the word trying and the phrase for a long time (in She's been trying to take them out for a long time) carries an implicit meaning that Trump is skeptic that Clinton (if elected as a president) would be able to defeat ISIS in Iraq. Then, he has gone back again to the same proposition of Obama and Secretary Clinton's misbehavior of leaving no troops in Iraq to protect it against the forming of ISIS.

In the last part of the extract, Trump has blamed Obama and Secretary Clinton for forming ISIS but for a different reason; not taking the oil of Iraq. This time, Trump's rich economic background and his former job as a businessman has been shown in lexicalization through emphasizing the issue of oil by repeating the word oil six times in addition to the phrase primary source of income (referring to oil) which also contradicts Clinton's previous statement that ISIS is primarily funded by foreigners. He has even described Clinton's ignorance of the issue of oil as a disaster in another one of her disasters.

The local semantic analysis of the extract above has revealed two ideologies for Trump towards Iraq: victimization and exploitation (protecting Iraq to exploit the Iraqi oil).

Then the moderator (Holt) terns to Clinton giving her a chance to respond to Trump's accusations of creating disasters in Iraq as shown in the following extract: 


\section{HOLT: Secretary Clinton?}

CLINTON: Well, I hope the fact-checkers are turning up the volume and really working hard. Donald supported the invasion of Iraq.

TRUMP: Wrong.

CLINTON: That is absolutely proved over and over again.

TRUMP: Wrong. Wrong.

CLINTON: He actually advocated for the actions we took in Libya and urged that Gadhafi be taken out, after actually doing some business with him one time.

CLINTON: But the larger point-and he says this constantly-is George W. Bush made the agreement about when American troops would leave Iraq, not Barack Obama.

And the only way that American troops could have stayed in Iraq is to get an agreement from the then-Iraqi government that would have protected our troops, and the Iraqi government would not give that.

But let's talk about the question you asked, Lester.... How do we prevent attacks? How do we protect our people?

(https://www.washingtonpost.com/news/the-fix/wp/2016/09/26/the-first-trump-clinton-presidential-debate-t ranscript-annotated).

Clinton has accused Trump of supporting the invasion of Iraq, but Trump has responded immediately that he did not do that using the word wrong which he has repeated for three times. Whenever the American invasion of Iraq is mentioned, Trump is accused either by Clinton or the moderator that he supported the war a matter which he has strongly denied using words (wrong) and sentences (I did not support the war in Iraq, I was against the war in Iraq, they did an article which had me totally against the war in Iraq). He has accused Clinton to create mainstream media nonsense about him supporting the war in Iraq. Then, Clinton has defended Obama saying that it was George W. Bush's decision to withdraw the American troops from Iraq because the Iraqi government then did not agree to protect the troops. This proposition carries contradiction because the American troops are supposed to stay in Iraq to protect Iraq and not to be protected by the Iraqi government then. Then, Clinton has suddenly changed the topic about Iraq to go back to the main topic about securing America against cyber- attacks. Clinton's ideology of evasion is apparent in her contradictory propositions, in accusing Trump of supporting the invasion of Iraq (to say that it was not only the decision of her government then) and in shifting the topic to save herself from more confrontation.

The identification of speech acts in the tree debates has been performed according to Vanderveken (1990, pp. 166-220). Starting with Clinton's speech parts of the debate mentioned above, the majority of the speech acts issued by Clinton, when speaking about Iraq, are assertions in which she has tried to:

1) Persuade the audience that Obama's government, in which she has been a secretary of state, has made progress in fighting ISIS in Iraq

2) Guess that they (the government) have been about to get Iraq free of ISIS soon

3) Claim that the ISIS are mainly dependent on foreign support and that the American troops left Iraq because the Iraqi government then refused to offer protection for the troops

4) State what she has already done to defeat terrorists in Iraq

5) Accuse Trump of supporting the war in Iraq in 2003.

Other speech acts issued by Clinton are directives in the form of promises to defeat ISIS and secure Iraq of any terrorist forces that might take Iraq as a base to cyber- attack the world (including America). According to the assertive speech acts, trying to persuade the audience of achieving progress over terrorists in Iraq, guessing to terminate ISIS at a particular definite time and stating previous victory achievements over terrorist forces reveal Clinton's ideology of exploitation over Iraq. She has exploited the changing situation in Iraq for her own benefit to show the audience that she is a powerful future president who is able to overcome the foreign terrorist forces that threaten America. In addition to exploitation, the ideology of domination has appeared through the assertive speech acts mentioned above which show that America has the ability to do what it believes to be necessary to do in Iraq.

The other assertive speech acts (claiming that the ISIS forces have been strengthened by foreign support and accusing Trump of supporting the war in Iraq) have reinforced Clinton's evasion ideology. Clinton has tried to give up her responsibility (as a member in the previous governments) in overthrowing the Iraqi regime and 
creating vacuum for Al- Qaida and ISIS to form in Iraq.

The promises she has issued to defeat ISIS and kill their leader in Iraq have revealed the restorative ideology; to expel ISIS from Iraq to restore its security from being a base for terrorist to launch their cyber- attacks against America.

Moving to Trump's speech parts about Iraq in this debate, the majority of the speech acts he has made, as is the case with Clinton, are assertions in which he has:

1) Reminded the audience of Clinton's previous assertion to show that Clinton has acted the opposite of what she has asserted

2) Accused Clinton, as a secretary of state in the previous government, of creating a vacuum the way they withdraw the American troops from Iraq

3) Disclaimed Clinton's statement about taking ISIS out of Iraq

4) Blamed The previous government for ISIS control over Iraq

5) Denied Clinton's accusation of him supporting the 2003 war in Iraq

6) Reasserted two issues; the first is his previous deny for Clinton's accusation of him supporting the 2003 war in Iraq by saying Wrong. Wrong and then saying I did not support the war in Iraq The second thing he has reasserted is the assertion which he has issued in other occasions (the issue of the Iraqi oil)

7) Corrected the moderator's and Clinton's assertions concerning his support of the war in Iraq

8) Described (by series of assertions) the steps that he has made before to stand against the war in Iraq.

The assertive speech acts of reminding, accusation, disclaim and blaming, on the one hand, reveal the ideology of victimization which has already been revealed in the local and global semantic analysis; Iraq is the victim of the previous governments' misbehavior. The assertive speech acts of denying his support of the war in Iraq, reasserting his deny for Clinton's accusation of him supporting the 2003 war in Iraq, correcting the moderator's and Clinton's assertion concerning his support for the war in Iraq and describing his stand in rejecting the war in Iraq, on the other hand, reveal the ideology of repudiation; he has repudiated any support for the 2003 war in Iraq. Moreover, the assertive speech act of reasserting that America should have taken the Iraqi oil in order to deprive the ISIS from an important funding source manifests the ideology of exploitation which has also appeared in the local semantic analysis.

The following table clarifies the first debate ideologies of both Clinton and Trump towards Iraq for each part of the analysis:

Table 3. The first debate ideologies

\begin{tabular}{lll}
\hline Clinton's ideologies & Trump's ideologies & Linguistic Device \\
\hline $\begin{array}{l}\text { apprehension } \\
\text { insecurity }\end{array}$ & victimization & global Topics \\
\hline $\begin{array}{lll}\text { domination } \\
\text { evasion }\end{array}$ & $\begin{array}{l}\text { victimization } \\
\text { exploitation }\end{array}$ & local semantics \\
\hline exploitation & victimization & speech acts \\
domination & repudiation & \\
evasion & exploitation & \\
restorative & & \\
\hline
\end{tabular}

\subsection{The Second Debate}

The participants are again the Democratic nominee, Hillary Clinton, and the Republican nominee, Donald J. Trump. The debate was held in October 9, 2016. As is the case with the first debate, the moderator has asked each nominee the same set of questions and two minutes have been allotted for each response.

As far as global topics are concerned, the moderator's question has not been put into consideration in the analysis since it does not represent the opinion of any of the nominees. The global topics related to Iraq for the nominees of the two parties are as follows: 
Table 4. Clinton's global topics in the 2nd debate

\begin{tabular}{ll}
\hline Clinton & \\
\hline 1 & Trump has been lying when he claimed he was against the war in Iraq. \\
2 & The American Special Forces' achievements in Iraq represent a good incentive to send the same \\
& forces (rather than troops) to Syria. \\
3 & America is about to defeat ISIS in Iraq and take Mosul back from them. \\
4 & It is necessary to arm the Kurds so that they (together with the Arabs) can help America to push \\
& ISIS out of Iraq first and then Syria.
\end{tabular}

Table 5. Trump's global topics in the 2nd debate

\begin{tabular}{ll}
\hline Trump \\
\hline 1 & America's war in Iraq has had bad effects on America and Iraq. \\
2 & $\begin{array}{l}\text { The war in Iraq was a bad decision of Clinton; Trump did not support the war } \\
3\end{array}$ \\
$\begin{array}{l}\text { Obama's and Clinton's misbehavior of creating a vacuum in Iraq encouraged ISIS to form and spread to } 32 \\
\text { other places }\end{array}$ \\
$\begin{array}{l}\text { The government's wrong foreign policy of announcing to attack ISIS in Mosul caused the ISIS leaders to } \\
\text { run away from Mosul }\end{array}$ \\
\hline
\end{tabular}

Both nominees have used the issue of Iraq to implicate certain implicit meanings. As for Clinton, there have been two general implicated meanings detected from her speech: the first is when she has accused Trump of supporting the war of Iraq implicating that it was not only her or the other government members' fault, and the second is when she has talked about her achievements in fighting ISIS in Iraq implicating that she can achieve victory over any terrorist threats that might threaten America in one way or another. Trump's implicated meanings are apparent first when he has blamed Clinton and others of making bad decisions in starting the war in Iraq and then leaving a vacuum for ISIS to form implicating, as a presidential competitor, that Clinton is not the right choice for presidency and, second, when he has insisted that he has never supported the war in Iraq implicating that he is wiser than supporting such a wrong decision. Accordingly, and depending on the global topics above, both Clinton and Trump have shown the exploitation ideology towards Iraq, but each one of them has different motives. Clinton, on the one hand, has used Iraq as a pretext to talk about her (supposed to be) positive achievements there and to embroil Trump in the 2003 war in Iraq. Trump, on the other hand, has used Iraq (talking about how the ISIS could seize a main Iraqi city, Mosul, and spread to other nations) as a pretext to talk about Clinton's inadequacy as a president.

At the level of local semantics, the analysis starts with Clinton's speech parts in the debate as shown in the following extract:

And the final thing I would say, this is the 10th or 12th time that he's denied being for the war in Iraq. We have it on tape. The entire press corps has looked at it. It's been debunked, but it never stops him from saying whatever he wants to say.... (https://www.nytimes.com/2016/10/10/us/politics/transcript-second-debate.html).

I do think the use of special forces, which we're using, the use of enablers and trainers in Iraq, which has had some positive effects, are very much in our interests, and so I do support what is happening, but let me just.... (https://www.nytimes.com/2016/10/10/us/politics/transcript-second-debate.html).

I hope by the time I am president that we will have pushed ISIS out of Iraq. I do think that there is a good chance that we can take Mosul. And, you know, Donald says he knows more about ISIS than the generals. No, he doesn't.

There are a lot of very important planning going on, and some of it is to signal to the Sunnis in the area, as well as Kurdish Peshmerga fighters, that we all need to be in this. And that takes a lot of planning and preparation.

I would go after Baghdadi. I would specifically target Baghdadi, because I think our targeting of Al Qaida leaders - and I was involved in a lot of those operations, highly classified ones-made a difference. So I think that could help.

I would also consider arming the Kurds. The Kurds have been our best partners in Syria, as well as Iraq. And I know there's a lot of concern about that in some circles, but I think they should have the equipment they need so that Kurdish and Arab fighters on the ground are the principal way that we take Raqqa after 
$\begin{array}{lcr}\text { pushing } & \text { ISIS } & \text { out }\end{array}$

In the first paragraph of the extract, Clinton has stated some propositions about Trump: Trump has denied supporting the war in Iraq for 10 or 12 times, there are tape records that prove he has supported the war, all press corps knows about these records and Trump ignores the records and press and says what he wants. Clinton has put the propositions in a clever sequence (starting with public objective facts then using but to state a contradictory proposition which represents Trump's opinion). Reading these sentences together, one can arrive at the entailment that Trump is a liar; it is obvious that this entailment has been part of Clinton's mental models about Trump. The lexicalization she has used (denied, we have on tape, press corps has looked at it, debunked and whatever he wants to say) helps a lot in inferring the intended meaning.

The second paragraph of the extract has come as a response to the moderator's question about what she intends to do in Syria. In her response, she has mentioned her (supposed to be) positive achievements in Iraq as an example of what she intends to do in Syria. Again (as is the case in the first debate), Clinton has killed two birds with one stone: on the one hand, she has answered the moderator's question about Syria with optimistic sense implicating that her government is acting wisely in Syria. On the other hand, she has referred to what she thinks to be positive achievement in Iraq in order for the audience to be aware of them. There has been a sense of positivity which has been indicated by lexicalization: I do think, positive effects, very much in our interest, I do support what is happening and there is a good chance; the implicature here is refutation of Trump's accusation that Clinton's policy in Iraq is a mistake.

As a response to the moderator's question of what Clinton would do differently from Obama when she becomes president (in relation to Iraq and Syria), Clinton's response has come in the last four paragraphs of the extract above. Clinton's positive tone has extended to this part of the extract but with more confidence; this time she has assured victory over ISIS and liberating Mosul then liberating Syria. She has talked about American plans in progress about involving Sunnis and Kurdish Peshmerga fighters in the fight against ISIS ignoring any reference to mutual plans with the Iraqi government making it a battle between America and ISIS; she has indicated that America has the upper hand in deciding who fights whom. The implicature here is that she has saved the American troops from the battle depending on the different Iraqi fighting categories and nationalities (Kurdish and Arab fighters on the ground are the principal way that we take Raqqa after pushing ISIS out of Iraq). This could be a response to Trump's accusation of withdrawing the American troops and creating a vacuum in Iraq. What is noticeable in her speech here is the absence of the Iraqi government's role in all that planning and decisions of America in Iraq. Reading this part of the script, one immediately remembers the sovereignty allegation of the $30^{\text {th }}$ of June, 2004. It is clear that dominating Iraq is a vital part of Clinton's mental model and this domination keeps showing explicitly and implicitly. Moreover, for the second time in this debate, Clinton has stated a proposition that carries the implicature that Trump is a liar; Donald says he knows more about ISIS than the generals. No, doesn't. (https://www.nytimes.com/2016/10/10/us/politics/transcript-second-debate.html .

The Local semantic analysis above reveals Clinton's ideologies of domination (America makes decisions and plans about what should happen in Iraq and who should be equipped and armed) and exploitation (she has used the critical situation in Iraq for her own benefit appearing as a decisive powerful presidential nominee who is able to make wise decisions to defeat powerful enemies).

As for Trump, his statements have focused on four propositions. The first two (the ones which Trump keeps repeating in different ways and different occasions) are that the war of Iraq was a mistake and that the withdrawal of the American troops has created a chance for ISIS to form; as shown in the following extracts:

First of all, Captain Khan is an American hero, and if I were president at that time, he would be alive today, because unlike her, who voted for the war without knowing what she was doing, I would not have had our people in Iraq. Iraq was disaster. So he would have been alive today... (https://www.nytimes.com/2016/10/10/us/politics/transcript-second-debate.html).

And, again, Bernie Sanders, it's really bad judgment. She has made bad judgment not only on taxes. She's made bad judgments on Libya, on Syria, on Iraq. I mean, her and Obama, whether you like it or not, the way they got out of Iraq, the vacuum they've left, that's why ISIS formed in the first place. They started from that little area, and now they're in 32 different nations, Hillary. Congratulations. Great job (https://www.nytimes.com/2016/10/10/us/politics/transcript-second-debate.html).

In the first extract, the issue of the moderator's question has been about Trump's policy towards Muslims in the United States, but Trump has cleverly deviated from the genuine answer making the answer in his favor to attack 
Clinton. Trump has used the death of Captain Khan (a Muslim officer in the United States army who was killed in a suicide attack in Iraq in 2004) as a means to attack Clinton for voting for the war of Iraq which has cost America many casualties like Captain Khan. Trump, here, has played with words to be more effective describing Captain Khan as an American hero who would be alive today if Trump was president at that time, but America has lost that hero because Clinton voted for the war without knowing what she was doing. Then, there is metonymy when he has used the word Iraq to refer to the war itself describing it as a disaster created by Clinton's bad decision; Iraq was disaster. Trump has talked as a pure presidential election nominee because such implementation of lexicalization and the propositions he sticks to are for the favor of election purposes implicating that Trump, rather than Clinton, is the right president.

In the second part of the extract, Trump has also deviated from the issue of the moderator's question which was about taxes in America and has directed the subject towards Libya and Syria reaching to Iraq in which America has played a considerable role. Trump's statements have focused on the same two propositions mentioned above (the war of Iraq and the vacuum created by the early departure of the American troops) in addition to blaming Clinton for the spread of ISIS to 32 different places. Moreover, to criticize Clinton, he has used irony twice, Congratulations and Great job, in which the literal meaning is the opposite of the real figurative meaning implicating that Clinton has already made bad judgements in both the interior and foreign policies.

The third proposition that Trump has focused on is Clinton's stupid American foreign policy (as he has called it) as shown in the following extract:

Now, she talks tough, she talks really tough against Putin and against Assad. She talks in favor of the rebels. She doesn't even know who the rebels are. You know, every time we take rebels, whether it's in Iraq or anywhere else, we're arming people. And you know what happens? They end up being worse than the people (https://www.nytimes.com/2016/10/10/us/politics/transcript-second-debate.html).

Let me tell you something. You take a look at Mosul. The biggest problem I have with the stupidity of our foreign policy, we have Mosul. They think a lot of the ISIS leaders are in Mosul. So we have announcements coming out of Washington and coming out of Iraq, we will be attacking Mosul in three weeks or four weeks (https://www.nytimes.com/2016/10/10/us/politics/transcript-second-debate.html).

[F]or weeks-I've been reading now for weeks about Mosul, that it's the harbor of where-you know, between Raqqa and Mosul, this is where they think the ISIS leaders are. Why would they be saying - they're not staying there anymore. They're gone. Because everybody's talking about how Iraq, which is us with our leadership, goes in to fight Mosul (https://www.nytimes.com/2016/10/10/us/politics/transcript-second-debate.html).

In the first part of the extract, Trump has made two contradictory statements to describe Clinton's foreign policy (She talks in favor of the rebels; She doesn't even know who the rebels are and every time we take rebels, whether it's in Iraq or anywhere else, we're arming people...; They end up being worse than the people) implicating Clinton's unwise foreign policy.

The statements in the last two parts of extract are concerned with how Iraq and America have been preparing to liberate Mosul (a major Iraqi city seized as a base by ISIS); there have been prior announcements that ISIS are going to be attacked in Mosul within few weeks. Trump has repeatedly stated this proposition implicating the bad American policy of announcing for the upcoming attack and giving a chance for the ISIS leaders to flee from Mosul. In the second part of the extract, he has blamed both Iraq and America for such announcements; we have announcements coming out of Washington and coming out of Iraq. In the third part of the extract, he directed the blame to America only (saying: everybody's talking about how Iraq, which is us with our leadership, goes in to fight Mosul) implicating that it is mainly an American mistake and implicitly meaning that Iraq's decisions and announcements are dominated by the American leadership.

The fourth proposition of Trump's statement and the one which he has kept insisting at is that he has always been against the war of Iraq refuting any pieces of evidence of him supporting the war and accusing Clinton of it:

I was against-I was against the war in Iraq. Has not been debunked. And you voted for it. And you shouldn't have. Well, I just want to say.... (https://www.nytimes.com/2016/10/10/us/politics/transcript-second-debate.html)

The local semantic analysis of Trump's speech in the second debate has revealed four ideologies. The first is victimization; Iraq is the victim of America's stupid foreign policy and bad decisions. The second is repudiation; Trump has claimed that he has always been against the war of Iraq, he has refused the departure of the American troops and refused the stupid foreign American policy towards Iraq. He has set himself free from 
being guilty about any American misdeed in Iraq. The third ideology is exploitation; he has, in many occasions, deviated from the moderator's genuine question and directed his answer towards the issue of the critical situation in Iraq to weaken his opponent's (Clinton's) position as a presidential nominee. The fourth ideology is domination; America has the power to launch a war against Iraq and subdue the regime there, Iraq is weak without the protection of the American troops, Iraq's announcements are subjected to American announcements and America can choose the kind of people to be armed in Iraq.

When speaking about Iraq, Clinton has mainly issued assertive speech acts in which she has:

1) Reasserted that there are pieces of evidence that Trump has supported the war of Iraq

2) Affirmed that the use of Special Forces, enablers and trainers, instead of troops, in Iraq is one of her priorities

3) Declared some of the American plans in Iraq about involving different Iraqi Sects in the fight against ISIS and arming people there

4) Reminded the audience about her role in killing some of Al- Qaida leaders in Iraq

5) Admitted some concerns about arming people in Iraq.

In addition to the above assertive speech acts, Clinton has also issued the commissive speech act of promise twice: the first has been about pushing ISIS out of Iraq and liberating Mosul and the second has been about targeting Al- Baghdadi (an ISIS leader).

The speech act analysis of Clinton's speech in the debate has revealed the ideologies of defense which can be inferred from her plans to send Special Forces and enablers to Iraq and arming some people there to help Iraq in fighting ISIS, promising to push ISIS out of Iraq and promising to liberate Mosul. There is also the ideology of domination which can be elicited from the way she has talked about her intentions and plans about the situation in Iraq; she has talked from a biased view point (American view point) without any reference to what Iraq (government and people) think about the American plans on its lands. Moreover, the ideology of exploitation is apparent in two points in her speech. First, in here speech about the bright future of Iraq if she becomes a president, there is the implicit meaning that she is determined to terminate ISIS in Iraq (she has used the situation in Iraq as a sort of electoral propaganda). Second, she has used the war of Iraq as a means to weaken the position of her opponent (Trump) when she has accused him of supporting the war of Iraq.

As is the case with Clinton, the major speech acts in Trump's speech are assertive speech acts in which he has:

1) Praised Captain Khan as an American hero who died during the War in Iraq

2) Postulated that if he had been a president before the war of Iraq, Captain Khan would not have died

3) Criticized (twice) Clinton for supporting the war of Iraq with no awareness of the consequences and for her bad foreign policy in Iraq in announcing about America's intention about liberating Mosul giving a chance for ISIS leaders to flee Mosul

4) Asserted that the war of Iraq was a disaster and how America has armed people in Iraq

5) Reasserted that he was against the war of Iraq and that Clinton has made bad judgements in Iraq

6) Negated the existence of any evidence of him supporting the war of Iraq

7) Blamed Clinton for voting for the war of Iraq and for creating vacuum in Iraq and for arming people in Iraq without really knowing who those people are

8) Stated an example of Clinton's bad foreign policy represented by Mosul

In addition to assertive speech acts, Trump has issued the expressive speech acts of congratulation and praising ironically directing his speech to Clinton and describing how he thinks about her for supporting the war of Iraq, creating a vacuum in Iraq and giving a chance for ISIS to form saying: Congratulations. Great job. Trump has indirectly meant to blame Clinton for her misbehavior in Iraq.

Accordingly, Trump appears to have three ideologies towards Iraq. The first is victimization; Iraq is the victim of the unwise American policy. The second is repudiation; he has cleared himself from any charge of supporting the war of Iraq. The third is exploitation; he has used the situation in Iraq as a means to make Clinton appear as an unsuccessful governor changing the situation to his favor.

According to the previous critical discourse analysis of the second debate, Clinton and Trump have shown the ideologies clarified in the table below: 
Table 6. The second debate ideologies

\begin{tabular}{lll}
\hline Clinton's ideologies & Trump's ideologies & Linguistic Device \\
\hline exploitation & exploitation & global topics \\
\hline exploitation & victimization & local semantics \\
domination & repudiation & \\
& exploitation & \\
& domination & \\
\hline defense & victimization & speech acts \\
domination & repudiation & \\
exploitation & exploitation & \\
\hline
\end{tabular}

\subsection{The Third Debate}

As is the case with the previous two debates, the participants were Clinton and Trump. The third debate was the final one which was held at the Thomas and Mack Center at the University of Nevada in Las Vegas in October 19, 2016. The dominant topics that the moderators have focused on were the Supreme Court and economy. Ignoring the topics of the moderator's questions (since they do not represent any of the nominees' opinions even though the questions have been about Iraq), the global topics of both Clinton and Trump have been as follows:

Table 7. Clinton's global topics in the 3rd debate

\begin{tabular}{ll}
\hline Clinton \\
\hline 1 & There are online pieces of evidence that Trump supported the war of Iraq but he keeps denying that he did \\
2 & $\begin{array}{l}\text { The Government's plan then is to take Mosul back and go after Al Baghdadi (a chief ISIS leader) then } \\
\text { move to liberate Raqqa }\end{array}$ \\
3 & $\begin{array}{l}\text { Trump's conspiracy theory (that Secretary Clinton at that time and the Iraqi government have been } \\
\text { determined to liberate Mosul for election purposes) is wrong }\end{array}$ \\
\hline
\end{tabular}

Table 8. Trump's global topics in the 3rd debate

\begin{tabular}{ll}
\hline Trump \\
\hline 1 & $\begin{array}{l}\text { Obama and Clinton have embroiled Iraq and many other nations in ISIS by launching the war in Iraq } \\
\text { then leaving a vacuum there and ISIS formed and speared }\end{array}$ \\
2 & Clinton's accusation that Trump has supported the war of Iraq is a false claim \\
3 & Mosul was a free place but the misbehavior of Obama and Clinton led ISIS to take it over \\
& The government's stupid foreign policy of announcing to attack ISIS in Mosul has caused the ISIS \\
& leaders to run away from Mosul
\end{tabular}

Apparently, both Clinton and Trump have focused on almost the same global topics about Iraq that have already been identified in the second debate. Both have focused on certain issues that they can use to condemn each other's deeds about Iraq to indicate certain implicit meanings.

Clinton's global topics have two implicature points: first, that Trump's statements have not been precise when he has alleged that he has not supported the war of Iraq and when he has accused Clinton of fighting ISIS in Iraq and other places for election purposes and, second, that she has positive attitude towards Iraq in that it is one of her priorities to help Iraq push ISIS out of its lands. Both of these implicature points lead to the identification of exploitation ideology towards Iraq; Clinton has used Iraq to show the audience what kind of person Trump is and to show them her strict attitude, as a presidential candidate, towards terrorism. Moreover, she has also shown the restorative ideology in stating her plans to take Mosul from ISIS and push them out of Iraq.

Trump's global topics reveal the implicature that Clinton is unsuitable president because, first, she has already made bad decisions in supporting the war of Iraq and then creating a vacuum for ISIS to form and, second, she has shown sever stupid foreign policy when she announced about America's intention to fight ISIS in Mosul giving a chance for ISIS leaders to run away from Mosul. This leads us to Trump's ideology of exploitation; he has used America's role in Iraq as a means to weaken Clinton's popularity and position as a presidential nominee. In addition, there is also the ideology of victimization; the ISIS disasters in Iraq have been created by Obama's and Clinton's bad decisions.

As for the local semantic analysis of Clinton's speech, she has insisted on the already repeated proposition (in the 
first and second debates) that Trump has supported the war of Iraq and that he has denied this documented fact:

CLINTON: Well, you know, once again, Donald is implying that he didn't support the invasion of Iraq. I said it was a mistake. I've said that years ago. He has consistently denied what is...

TRUMP: Wrong.

CLINTON: ... a very clear fact that...

TRUMP: Wrong.

CLINTON: ... before the invasion, he supported it. And, you know, I just want everybody to go Google it. Google "Donald Trump Iraq." And you will see the dozens of sources which verify that he was for the invasion of Iraq.

TRUMP: Wrong.

CLINTON: And you can actually hear the audio of him saying that. Now, why does that matter? Well, it matters because he has not told the truth about that position. I guess he believes it makes him look better now to contrast with me because I did vote for it. (https://www.washingtonpost.com/news/the-fix/wp/2016/10/19/the-final-trump-clinton-debate-transcript-an notated)

Apparently, she has implicitly meant that she is not the only one to be blamed for the war of Iraq and, at the same time, she has condemned her opponent to tell the audience (again implicitly) that Donald is not wiser than her concerning the war issue. The ideology of exploitation can be triggered here in exploiting Iraq to fight her opponent. The exploitation ideology can also be triggered in another part of the debate when she has condemned Trump for his conspiracy theory of mistrusting Clinton which states that she has decided to fight ISIS in Iraq and Syria for election purposes:

I'm just amazed that he seems to think that the Iraqi government and our allies and everybody else launched the attack on Mosul to help me in this election, but that's how Donald thinks. You know, he always is looking for some conspiracy (https://www.washingtonpost.com/news/the-fix/wp/2016/10/19/the-final-trump-clinton-debate-transcript-an notated).

The third place where the exploitation ideology has been revealed is when Clinton has shown here determinism to terminate Al- Baghdadi implicating that she is a powerful nominee who practices what she preaches since she has already taken part in terminating Bin- Laden at a time in which Trump was busy with trivial issues. There is also the implicature that Trump has instable shallow personality and he has, so far, done nothing to America:

But what's really important here is to understand all the interplay. Mosul is a Sunni city. Mosul is on the border of Syria. And, yes, we do need to go after Baghdadi, and - just like we went after bin Laden, while you were doing "Celebrity Apprentice," and we brought him to justice. We need to go after the leadership (https://www.washingtonpost.com/news/the-fix/wp/2016/10/19/the-final-trump-clinton-debate-transcript-an notated).

In another part of the debate, she has talked with optimistic sense (I am encouraged....) about the fighting of ISIS in Iraq when it is mainly led by Iraqi and Kurdish forces and only supported by the American Special Forces. However, her optimistic tone has changed to be pessimistic when she has started talking about putting American soldiers in Iraq to fight ISIS. The pessimistic sense has been expressed in a number of propositions which has all started with hedges as follows:

Well, I am encouraged that there is an effort led by the Iraqi army, supported by Kurdish forces, and also given the help and advice from the number of special forces and other Americans on the ground. But I will not support putting American soldiers into Iraq as an occupying force. I don't think that is in our interest, and I don't think that would be smart to do. In fact, Chris, I think that would be a big red flag waving for ISIS to reconstitute itself. The goal here is to take back Mosul. It's going to be a hard fight. I've got no illusions about that.... (https://www.washingtonpost.com/news/the-fix/wp/2016/10/19/the-final-trump-clinton-debate-transcript-an notated).

The pessimistic tone, the propositions indicating the negative attitude towards having American soldiers to fight ISIS in Iraq and the use of hedges (indicating uncertainty) all reveal the ideology of insecurity towards Iraq as insecure place especially when she has said It's going to be a hard fight describing the upcoming battle with ISIS The insecurity ideology has been reinforced when Clinton has considered Iraq as a source of threat to the 


\section{American security:}

And, yes, some of that threat emanates from over in Syria and Iraq, and we've got to keep fighting.... (https://www.washingtonpost.com/news/the-fix/wp/2016/10/19/the-final-trump-clinton-debate-transcript-an notated).

Another ideology for Clinton that local semantic analysis has revealed is justification; she has justified what Trump has called stupid foreign policy (of announcing America's intention to help fighting ISIS in Iraq) saying that it does not matter that ISIS fighters and leaders have taken their precautions and run away from Mosul because Clinton wanted to get rid of them and she was after Al- Baghdadi himself:

But what's really important here is to understand all the interplay.... And, yes, we do need to go after Baghdadi.... But we need to get rid of them, get rid of their fighters. There are an estimated several thousand fighters in Mosul. They've been digging underground. They've been prepared to defend.... (https://www.washingtonpost.com/news/the-fix/wp/2016/10/19/the-final-trump-clinton-debate-transcript-an notated).

As for Trump's speech, the local semantic analysis has shown the ideologies of exploitation, victimization and repudiation. The Exploitation ideology is apparent when he has used the deteriorated situation in Iraq to attack Clinton and accuse her of making bad decisions in Iraq and adapting a stupid foreign policy in dealing with the Iraqi situation. He has also accused her of fighting ISIS for election purposes. Trump's speech has the implicature that Clinton is unsuitable choice for presidency (a repeated implicature that Trump has stuck to in both of the previous debates). Trump's propositions in the following extracts have all been employed to imply the implicature above:

Take a look at Iraq. She gave us ISIS, because her and Obama created this huge vacuum, and a small group came out of that huge vacuum because ... we should never have been in Iraq, but once we were there, we should have never got out the way they wanted to get out....

We had Mosul. But when she left, when she took everybody out, we lost Mosul. Now we're fighting again to get Mosul....

About three months ago, I started reading that they want to get the leaders and they're going to attack Mosul. Whatever happened to the element of surprise, OK? ....

They want to look good. He ... made so many mistakes, made all the mistakes. That's why we have the great migration. But she wanted to look good for the election....

But the leaders that we wanted to get are all gone because they're smart. They say, what do we need this for? ....

You shouldn't have been in Iraq, but you did vote for it. You shouldn't have been in Iraq, but once you were in Iraq, you should have never left the way.... (https://www.washingtonpost.com/news/the-fix/wp/2016/10/19/the-final-trump-clinton-debate-transcript-an notated).

The exploitation ideology has also appeared when Trump has repeatedly stated the proposition that Iran has taken over Iraq by seizing the chance when America has created a vacuum in Iraq. Trump has used Iraq to attack Clinton for giving such a chance to Iran and, at the same time, to attack Iran for interfering with the Iraqi affairs:

Iran should write us yet another letter saying thank you very much, because Iran, as I said many years ago, Iran is taking over Iraq, something they've wanted to do forever, but we've made it so easy for them.... Iran is taking over Iraq.... Iran is taking over Iraq. We don't gain anything (https://www.washingtonpost.com/news/the-fix/wp/2016/10/19/the-final-trump-clinton-debate-transcript-an notated).

Another ideology that Trump has almost always adopted towards Iraq in the three debates is victimization. He has always tried to portray Iraq as a victim of the previous American governments. It goes without saying that victimization does not necessarily implicate sympathy because the political situation, especially in the critical case of presidential election, requires a firm personality that focuses on pure American interests. The only apparent implicature here is that Trump has wanted to weaken the position of Clinton by focusing on her misbehavior and bad decisions in Iraq.

Another ideology of Trump towards Iraq is repudiation which appears clearly when he has insisted on denying that he has supported the war of Iraq before; he has always tried to exonerate himself of any responsibility towards the deteriorated situation in Iraq: 
CLINTON: Well, you know, once again, Donald is implying that he didn't support the invasion of Iraq. I said it was a mistake. I've said that years ago. He has consistently denied what is...

TRUMP: Wrong.

CLINTON: ... a very clear fact that...

TRUMP: Wrong.

CLINTON: ... before the invasion, he supported it. And, you know, I just want everybody to go Google it....

TRUMP:

Wrong.

(https:/www.washingtonpost.com/news/the-fix/wp/2016/10/19/the-final-trump-clinton-debate-transcript-an notated).

Moving to speech acts, and as is the case with the previous two debates, both Clinton and Trump have mainly issued assertive speech acts. In her assertive speech acts, Clinton has mainly:

1) Stated the propositions that the Iraqi army and the Kurdish forces (supported by the American Special Forces) have been ready to fight ISIS, the reason why America and Iraq have announced about their intention to fight ISIS in Iraq, her astonishment about Trump's way of thinking and that she has not intended to send troops to fight ISIS in Iraq

2) Predicted the bad consequences of having American troops to fight ISIS in Iraq

3) Assured that the fight with ISIS is going to be a hard one

4) Accused Trump of supporting the war of Iraq and of thinking the conspiracy theory way about Clinton's determinism to fight ISIS in Iraq

5) Admitted that Iraq has been a source of threat to America

Moreover, as is the case with any presidential nominee, Clinton has issued the commissive speech act of promise to go after Al- Baghdadi and other ISIS leaders and to, eventually, defeat ISIS in Iraq and Syria.

Clinton's ideologies that can be inferred from speech acts are the insecurity and exploitation ideologies. The ideology of insecurity is clear in Clinton's fears of sending American troops to fight in Iraq and in considering Iraq a source of threat to America. The exploitation ideology is clear in insisting to accuse Trump of supporting the war of Iraq (to weaken his position as a nominee) and in her promises to defeat ISIS in Iraq and Al- Baghdadi himself taking advantage of these promises to strengthen her position as a presidential nominee.

In his assertive speech acts, Trump has:

1) Blamed Clinton for being in Iraq in 2003 then leaving a vacuum there and giving a chance for ISIS to form, for the taking over of Mosul by ISIS, for announcing the American plans to restore Mosul from ISIS and giving a chance for ISIS fighters to run away and for giving Iran a chance to take over parts of Iraq

2) Reasserted that Clinton has taken part in giving ISIS a chance to form and spread

3) Predicted that Clinton will never be able to get rid of ISIS as she has promised and that the upcoming fight with ISIS will be tough with huge casualties

4) Accused Clinton of intending to fight ISIS for election purposes

5) Criticized Clinton's foreign policy of announcing, in advance, America's intention to attack ISIS fighters in Mosul

6) Denied Clinton's accusation that he has voted for the war of Iraq in 2003 using the word wrong repeatedly as a response to Clinton's accusation.

The speech act analysis of Trump's speech reveals the ideologies of victimization, exploitation, repudiation and skepticism. The ideology of victimization appears when Trump has put Iraq into a victim situation when he has shed light on the fact that Iraq is a victim of the stupid policies of some American governors (the invasion of Iraq in 2003, leaving Iraq and creating a vacuum there after dropping the regime, giving a chance for ISIS to form, announcing about the plans and intentions to attack ISIS and giving a chance for Iran to take over parts of Iraq). The exploitation ideology has appeared when he has used the case of Iraq as an excuse to attack Clinton to weaken her stand as a presidential nominee. The repudiation ideology has been clarified when Trump denied that he has supported the war of Iraq in 2003. The ideology of skepticism is apparent when he has revealed his doubts about defeating ISIS in Iraq in case Clinton is elected as a president since the fight with ISIS is not an easy one. 
Thus, the critical discourse analysis of the third debate has revealed the following ideologies of both Clinton and Trump towards Iraq:

Table 9. The third debate ideologies of Clinton and Trump

\begin{tabular}{lll}
\hline Clinton's ideologies & Trump's ideologies & Linguistic Device \\
\hline exploitation & exploitation & global topics \\
restorative & victimization & \\
insecurity & exploitation & local semantics \\
exploitation & victimization & \\
justification & repudiation & \\
insecurity & exploitation & speech acts \\
exploitation & victimization & \\
& repudiation & \\
& skepticism & \\
\hline
\end{tabular}

\section{Conclusions}

The analysis of the three presidential debates held before the presidential elections in 2016 between the presidential nominees at that time (Clinton and Trump) has revealed the following conclusions:

1) Integrating Clinton's and Trump's ideologies towards Iraq appeared in each of the three debates, the following holistic table has resulted:

Table 10. The three debates ideologies of Clinton and Trump

\begin{tabular}{ll}
\hline Clinton's ideologies & Trump's ideologies \\
\hline domination & domination \\
apprehension & exploitation \\
evasion & repudiation \\
exploitation & skepticism \\
insecurity & victimization \\
defense & \\
justification & \\
restorative & \\
\hline
\end{tabular}

It is apparent from the table above that the three debates represent an ideologically rich discourse which has been employed in a way that reveals eight different ideologies for Clinton towards Iraq and other five different ones for Trump.

2). Both Clinton and Trump share the ideologies of domination and exploitation towards Iraq. They both consider America as having the superior global power that can dramatically change the situation in Iraq in a way which America decides. In their mental models, Iraq is a weak- willed country who is always in need of America to settle interior and foreign affairs. Domination may easily lead to exploitation; the dominant exploit the dominated. Both nominees have exploited certain issues about Iraq to confront each other and compete in their race towards the presidential office.

3). According to the analysis, out of the eight ideologies of Clinton, two ideologies carry positive attitude towards Iraq (defense and restorative) and the remaining six ones (exploitation, domination, apprehension, evasion, insecurity and justification) carry negative attitude towards Iraq. Concerning Trump's ideologies, out of five ideologies, four ones carry negative attitude (domination, exploitation, repudiation and Skepticism) and the remaining one (victimization) is neutral. Thus, both Clinton and Trump share this negative evaluation towards a country that Americans themselves claim that they have liberated form a tyrant regime and helped transforming it from an oppressed to democratic country. This claim is being refuted constantly once by the American authorities and political figures themselves (as is the case in this debate) and another time by tangible facts in the form of field pieces of evidence represented by the deteriorated situation in Iraq after 2003.

4). Clinton's ideologies of apprehension, insecurity, defense, restorative and domination can help, to a certain extent, form some expectation about America's plans and intentions in Iraq in case Clinton was the president. As for Trump, none of his ideologies gives a clear explicit indication of his future plans or intention in Iraq. His 
ideologies, excluding domination, have been employed to confront and attack Clinton for her mistakes and bad decisions concerning Iraq. The analysis of the three debates has not shown any promising speech act of Trump concerning Iraq. There are two probable explanatory reasons for that: first, Trump has been careful of his speech and did not want to say what he might not be able to perform in the future. Second, he is a supporter of the element of surprise to ensure the success of his plans. The second reason is the most probable one because, many times in the three debates, he has condemned Clinton's and the Iraqi government's announcements of their intention to attack and defeat ISIS and destroying the element of surprise.

It is hoped that the present paper helps political analysts to access a sort of objective analysis, especially concerning the American role in shaping the political situation in Iraq. The paper also makes vivid the fact that the American presidential debates represent an ideology rich discourse which provides chances for researchers to make their own contributions within the discourse in question.

\section{References}

Al-Momani, H. A. (2017). Political discourse of Jordan: a critical discourse analysis. International Journal of English Linguistics, 7(2), 90-98. http://dx.doi.org/10.5539/ijel.v7n2p90

Fairclough, N. (2001). Language and Power. London: Longman.

Fairclough, N. (2010). Critical Discourse Analysis: A Critical Study of Language. New York: Routledge. https://doi.org/10.4324/9780203809068.ch1

Fairclough, N., Mulderrig, J., \& Wodak, R. (2011). Critical discourse analysis. In T. A. Van Dijk (Ed.), Discourse Studies (pp. 357-378). Thousand Oaks: Sage. https://doi.org/10.4135/9781446289068.n17

https://www.nytimes.com/2016/10/10/us/politics/transcript-second-debate.html

https://www.washingtonpost.com/news/the-fix/wp/2016/09/26/the-first-trump-clinton-presidential-debate-transcr ipt-annotated

https://www.washingtonpost.com/news/the-fix/wp/2016/10/19/the-final-trump-clinton-debate-transcript-annotate $\mathrm{d}$

Jin, X., \& Shang, Y. (2015). A critical analysis of the Diaoyu Islands dispute in American news media. International Journal of English Linguistics, 5(2), 55-62. http://dx.doi.org/10.5539/ijel.v5n2p55

Khalil, H. H. (2017). A pragmatic analysis of vague language in the news articles on the Iraqi security crisis. Theory and Practice in Language Studies, 7(5), 327-335. https://doi.org/10.17507/tpls.0705.01

Searle, J. (1979). A Taxonomy of Illocutionary Acts in Expression and Meaning. Cambridge: Cambridge University Press.

Tenorio, E. H. (2011). Critical discourse analysis, an overview. Nordic Journal of English Studies, 10(1), 183-210.

Van Dijk, T. A. (1993). Discourse, power and access. In C. R. Caldas (Ed.), Studies in Critical Discourse Analysis (pp. 84-104). London: Routledge.

Van Dijk, T. A. (1993). Principles of critical discourse analysis. Discourse and Society, 4(2), 249-283. https://doi.org/10.1177/0957926593004002006

Van Dijk, T. A. (1998). Ideology: A Multidisciplinary Approach. London: SAGE.

Van Dijk, T. A. (2001). Multidisciplinary CDA: a plea for diversity. In R. Wodak \& M. Meyer (Eds.), Methods of Critical Discourse Analysis (pp. 95-119). London: Sage.

Van Dijk, T. A. (2002). Political discourse and political cognition. In P. A. Chilton, \& C. Schäffner (Eds.), Politics as Text and Talk. Analytical Approaches to Political Discourse (pp. 203-237). Amsterdam: John Benjamins. https://doi.org/10.1075/dapsac.4.11dij

Van Dijk, T. A. (2005). Contextual knowledge management in discourse production: a CDA perspective. In R. Wodak \& P. Chilton (Eds.), A New Agenda in (Critical) Discourse Analysis (pp. 71-100). Philadelphia: John Benjamins. https://doi.org/10.1075/dapsac.13.07dij

Van Dijk, T. A. (2009). Critical discourse studies: a sociocognitive approach. In R. Wodak \& M. Meyer (Eds.), Methods of Critical Discourse Analysis (pp. 62-86). London: Sage.

Van Dijk, T. A. (2016). Sociocognitive discourse studies. Chapter to appear in Handbook of Discourse Analysis (to be published by Routledge. J. Richardson \& J. Flowerdew (Eds.) 
http://www.discourses.org/OldArticles/Sociocognitive\%20Discourse\%20Studies.pdf

Van Dijk, T. A. (1995). Discourse analysis as ideology analysis. In C. Schaffner \& A. L. Wenden (Eds.), Language and Peace (pp. 17-33). Dartmouth: Aldershot.

Vandervekene, D. (1990). Meaning and Speech Acts: Principles of Language Use (Vol. 1). Cambridge: Cambridge University Press.

Waugh, L. R., Catalano, T., Al Masaeed, K., Hong Do, T., \& Renigar, P. G. (2016). Critical discourse analysis: definition, approaches, relation to pragmatics, critique, and trends. In A. Capone \& J. L. Mey (Eds.), Interdisciplinary Studiesnin Pragmatics, Culturenand Society (pp. 71-136). New York: Springer. https://doi.org/10.1007/978-3-319-12616-6_4

\section{Copyrights}

Copyright for this article is retained by the author(s), with first publication rights granted to the journal.

This is an open-access article distributed under the terms and conditions of the Creative Commons Attribution license (http://creativecommons.org/licenses/by/4.0/). 